\author{
Journal of Food Technology Research \\ 2021 Vol. 8, No. 2, pp. 58-66. \\ $\operatorname{ISSN}(e): 2312-3796$ \\ $\operatorname{ISSN}(p): 2312-6426$ \\ DOI: $10.18488 /$ journal.58.2021.82.58.66 \\ (C) 2021 Conscientia Beam. All Rights Reserved. \\ check for
updates
}

\title{
IMPROVING THE STORAGE QUALITY OF EGGPLANTS (Solanum Aethiopicum L.) FRUIT USING ALOE VERA GEL COATING
}

\author{
Rosemond \\ Godbless Dadzie ${ }^{1+}$ \\ Robert Sarpong \\ Amoah $^{2}$ \\ Jerry Ampofo- \\ Asiama $^{3}$ \\ Dright Quaye ${ }^{4}$ \\ Nazir Kizzie- \\ Hayford $^{5}$ \\ Ernest Ekow \\ Abano $^{6}$
}

\author{
${ }^{1,3,4}$ Department of Agricultural Engineering, University of Cape Coast, Cape \\ Coast Ghana. \\ 'Email:rdadzie@ucc.edu.gh \\ ${ }_{0,5,6}$ Department of Biochemistry, University of Cape Coast, Cape Coast, Ghana.
}

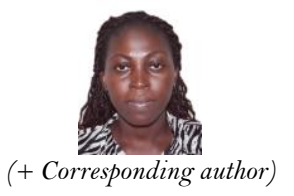

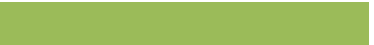

Article History

Received: 29 October 2021 Revised: 2 December 2021 Accepted: 16 December 2021 Published: 27 December 2021

\section{Keywords}

Aloe vera gel

Coating

Eggplant fruits

Storage

Postharvest loss.

\begin{abstract}
Aloe vera gel has been investigated as possible edible coating to help improve the storage life of fruits after harvest. The study sought to investigate the effect Aloe vera gel coating with or without citric acid pretreatment on the quality of eggplant fruits during low temperature storage and in shelf life. Briefly, eggplants were coated with Aloe vera gel (some fruits were pretreated with citrate prior to the coating) and the changes in physicochemical quality of the fruit measured during storage at $10^{\circ} \mathrm{C}$. After 14 days, however, some fruits were transferred for storage at room temperature until day 18. Coating with Aloe vera decreased moisture loss, and consequently, decreased weight loss and loss of firmness of the fruit. The coating did help maintain the phenolic content, ascorbate levels and antioxidant capacity of the fruit. Pre-treating the fruit with citrate did not improve quality, showing that Aloe vera gel can be applied alone to enhance the storage quality of eggplant fruit. Results obtained from this study shows that Aloe vera gel coating can be useful in extending the postharvest storage life and maintaining the quality of eggplant fruits during low temperature storage.
\end{abstract}

Contribution/Originality: This study contributes to the existing literature on postharvest application of edible coating on agricultural produce. This study uses locally available plant material (Aloe vera) for preparation of edible coating to improve the quality and storage life of eggplant fruits. Aloe vera gel can be used to reduce weight loss and color changes while maintaining firmness of eggplant fruits. Coating eggplant fruits with Aloe vera gel can result in the accumulation of phenolic compounds and ascorbic acid, which can increase the antioxidant capacity of the fruit. This implies that Aloe vera gel coating can preserve the potential health benefits of the fruit during storage.

\section{INTRODUCTION}

Excessive postharvest loss of fruits and vegetables is a major problem in many developing countries leading to heavy financial loss to farmers and threatening food security. Particularly, spoilage of fruit such as eggplants, which 
serve as an important component of most diets in West Africa (Owusu-Ansah, Afreh-Nuamah, Obeng-Ofori, \& Ofosu-Budu, 2001) was reported to amount to about $42 \%$ after harvest (Kitinoja \& AlHassan, 2012). Although low temperature storage could help preserve fruit quality, several tropical fruits have showed relatively short shelf life due to chilling injury. Exemplarily, eggplant fruit was reported to show noticeable loss in quality during storage at 10-12 ${ }^{\circ} \mathrm{C}$ after 14 days (Dadzie, Amoah, Ampofo-Asiama, Quaye, \& Abano, 2019). It is, therefore, important to investigate techniques to improve further the quality of eggplant fruit during low temperature storage.

Currently, the application of plant-based coatings such as vegetable waxes and gels to improve the quality of fruits during postharvest storage has generated a lot of scientific interest (Nicolau-Lapena et al., 2021). Among several other types of coatings, the application of Aloe vera gel is of special interest because of it is relatively inexpensive and biodegradable as well as having antimicrobial and anti-browning properties (Ergun \& Satici, 2012).

Application of Aloe vera gel in fruit coatings was reported to form an impermeable layer that limits the exchange of moisture and gases such as oxygen and carbon dioxide between the fruit and the environment (Nicolau-Lapena et al., 2021). This phenomenon resulted in a decrease in moisture loss and respiration, consequently, minimizing loss of fruit quality in terms of weight, firmness and colour (Ergun \& Satici, 2012). Aloe vera gel is reported to be tasteless, colorless and odorless, presenting additional advantages of minimal impact on the sensorial properties of fruit (Sharmin, Islam, \& Alim, 2015). Although the local availability of Aloe vera in many tropical countries of Africa contributes to the practical abundance and cost-effective utilization for reducing postharvest losses in fruits and vegetables, the application for improving the storage quality of eggplant fruit has not been investigated. This research was, therefore, aimed at investigating the potential of Aloe vera gel as possible coating agent to improve the postharvest storage of eggplant fruit.

\section{MATERIALS AND METHODS}

\subsection{Sample Preparation}

Commercially matured eggplant fruit (Solanum atheopicum L) of uniform size, shape and color were supplied by a farmer at Mankessim, Ghana. After discarding unwholesome fruit, sound fruit were washed thoroughly with water and disinfected with $1 \%$ sodium hypochlorite solution. Thereafter, fruit were rinsed with sterile water and air dried at room temperature.

Fresh Aloe vera leaves were collected from the Botanical Garden of the University of Cape Coast, washed to remove debris and disinfected for $5 \mathrm{~min}$ in $1 \%$ sodium hypochlorite solution. Subsequently, the core of the leaves was cut-open, the gel was scraped, homogenized using a mixer, and sieved through $45 \mu \mathrm{m}$ mesh.

\subsection{Coating and Storage of Eggplant Fruit}

Coating was carried out by dipping fruit in the gel for 5 min and leaving to dry under tropical-room conditions (25-32 ${ }^{\circ} \mathrm{C}$ ) for $1 \mathrm{~h}$. A separate portion of the fruit was pre-treated with $1 \%$ citrate for $5 \mathrm{~min}$ and air-dried for $1 \mathrm{~h}$ prior to coating. This treatment was carried out to determine whether Aloe vera gel coating can be applied alone or in combination with an antimicrobial/anti-browning agent to help improve the quality of the eggplant fruit during low temperature storage. Uncoated fruits were used as control.

Eggplant fruits were then transferred into a temperature-controlled chamber at $10{ }^{\circ} \mathrm{C}$ and samples taken periodically for analyses of changes in physicochemical properties. After $15 \mathrm{~d}$, some fruits were transferred for storage under room temperature $\left(32-35^{\circ} \mathrm{C}\right)$ to study the impact of uncontrolled storage temperature.

\subsection{Physicochemical Analyses}

The effect of the coating the quality of eggplant fruit was determined by measuring the changes in weight, color and firmness according to the procedure described by Dadzie et al. (2019) using an analytical balance, color reader (CS-10, CHN Spec, China) and digital fruit penetrometer (GY-4, Tsingtao Tokyo Instruments Co., Ltd, 
China), respectively. The effect of the coating phenolic content, antioxidant capacity and ascorbate level was also determined as described by Dadzie et al. (2019).

\subsection{Statistical Analysis}

Statistical analysis was performed using SPSS (IBM, SPSS Statistics 20). Differences between the treatments were analyzed using analysis of variance (ANOVA) and Tukey's multiple comparison test. Unless otherwise stated, arithmetic means are based on 9 determinations. Post-hoc analyses were carried out using the Tukey test. Pearson correlation coefficients were estimated between the measured physicochemical parameters. Principal component analysis (PCA) was also performed to explore associations between the different coating conditions and the measured physicochemical parameters.

\section{RESULTS AND DISCUSSION}

\subsection{Effect of Coating on Weight and Firmness of Eggplant Fruit}

Weight loss was observed for all fruit during storage, and was significantly higher among uncoated eggplants compared to both coated eggplants Figure 1. Loss of weight have been observed in fruit during low temperature storage, which is ascribed to water loss caused by metabolic activities during transpiration and respiration (NicolauLapena et al., 2021). In eggplant fruit increasing weight loss during storage has been reported (Dadzie et al., 2019; Singh et al., 2016). Similar to this study, decreases in weight loss in several fruits including papaya (Sharmin et al., 2015) and tomato (Chrysargyris, Nikou, \& Tzortzakis, 2016) were explained by the ability of aloe vera coating to limit moisture loss (Nicolau-Lapena et al., 2021).

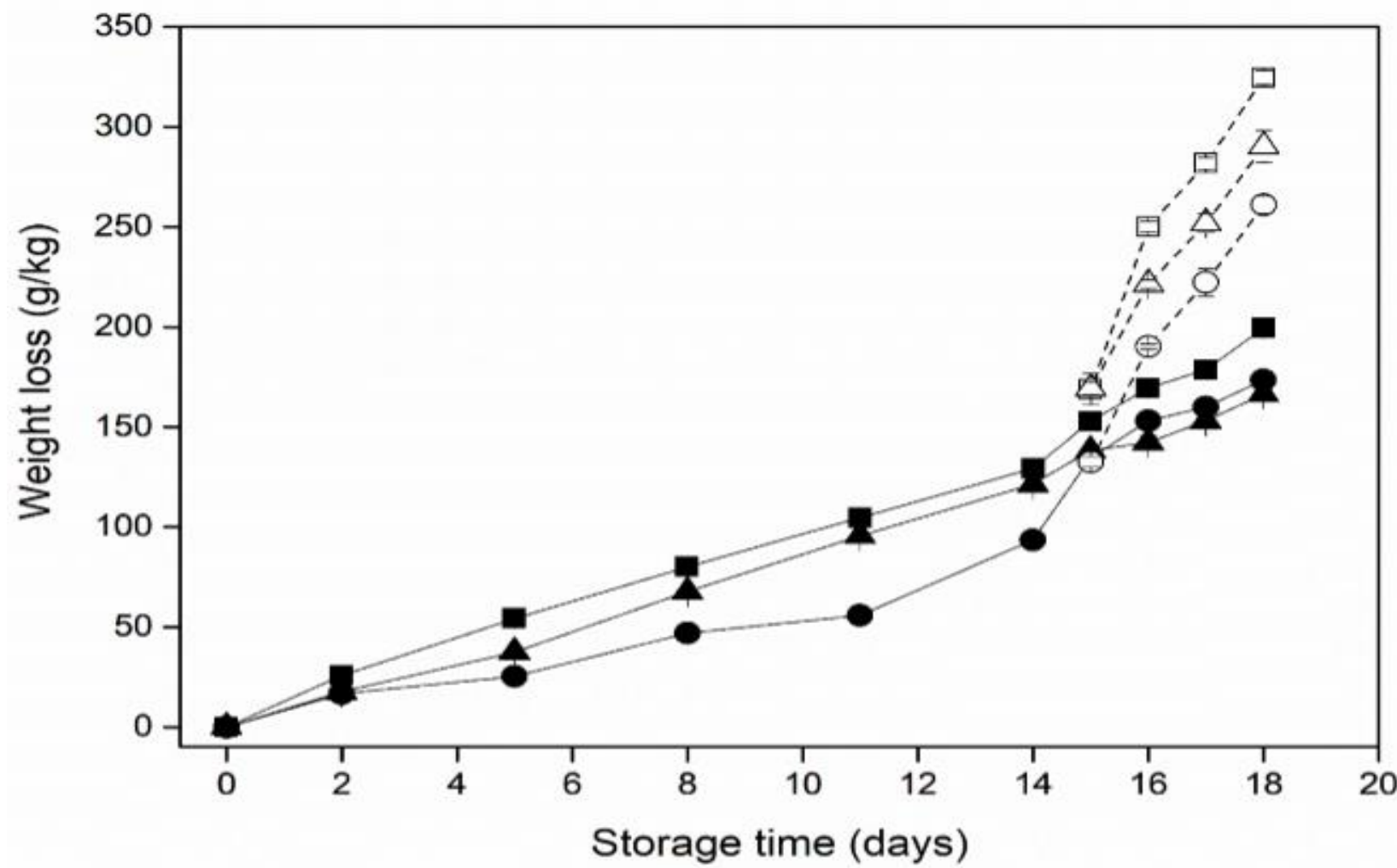

Figure-1. Weight loss of eggplant fruit during storage at $10^{\circ} \mathrm{C}$ (solid lines) [control fruit ( $\left.\mathbf{\square}\right)$; Aloe vera coated fruit $(\bullet)$; citrate pre-treated Aloe vera coated fruit $(\boldsymbol{\Delta})]$ and upon transfer to room temperature (dashed lines) after 14 days [control fruit ( $\square)$; Aloe vera coated fruit $(\circ)$; citrate pre-treated Aloe vera coated fruit $(\Delta)]$. 


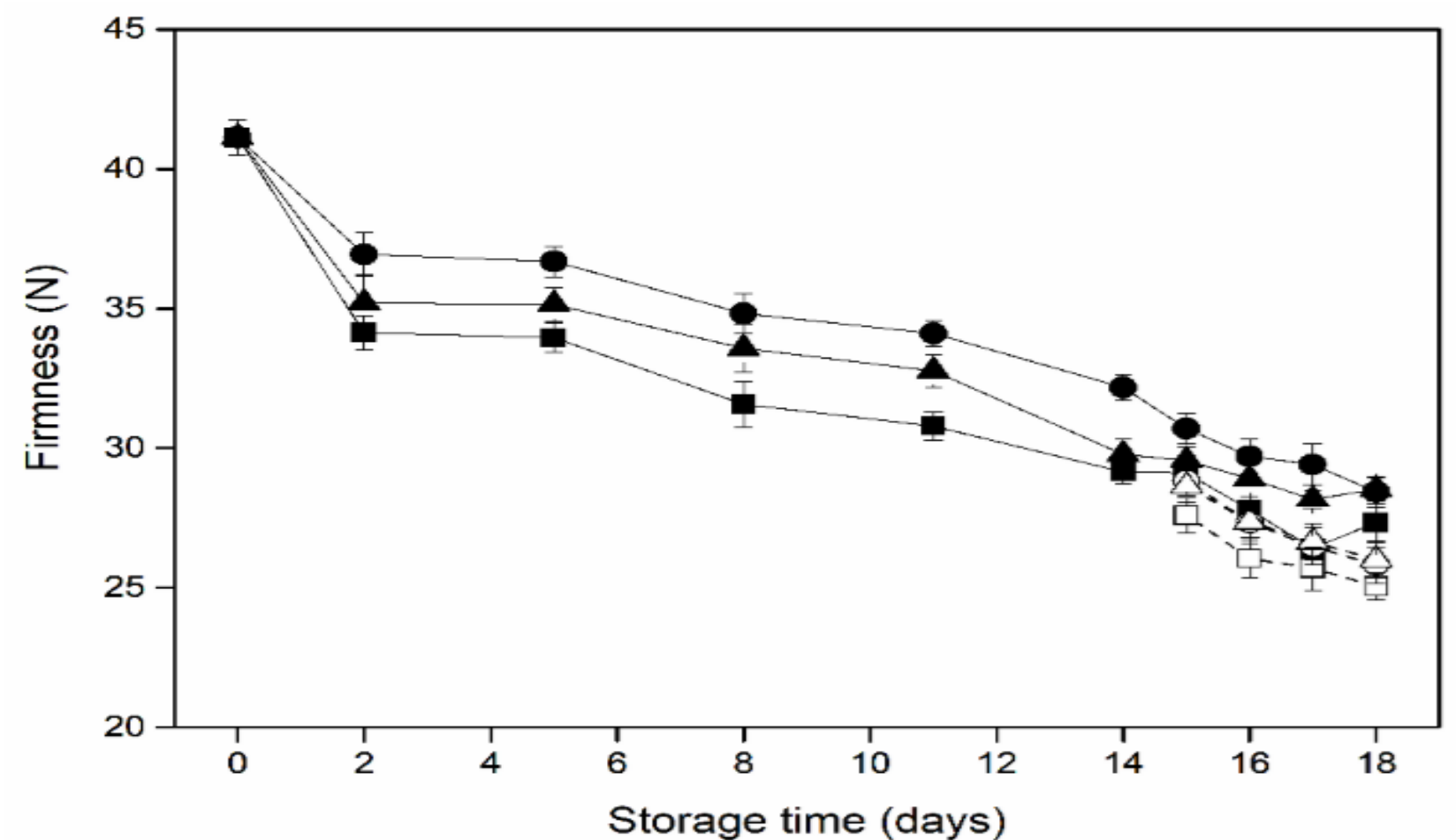

Figure-2. Firmness of eggplant fruit during storage at $10{ }^{\circ} \mathrm{C}$ (solid lines) days [control fruit (घ); Aloe vera coated fruit $(\bullet)$; citrate pre-treated Aloe vera coated fruit $(\boldsymbol{\Delta})]$ and upon transfer to room temperature (dashed lines) after 15 days [control fruit ( $\square$ ); Aloe vera coated fruit ( $\bigcirc$ ); citrate pre-treated Aloe vera coated fruit $(\Delta)]$.

The high rate of weight loss recorded for fruit transferred to room temperature after 15 days can be partly explained by an increased rate of metabolic activities or higher rate of moisture evaporation caused by the higher environmental temperature. Pre-treatment of eggplant with citrate was not effective in further reducing weight loss compared to only the coated fruit.

Fruit firmness decreased throughout the storage period (Figure 2), although the uncoated fruit recorded the lowest firmness. Similarly, reduced loss in firmness has been observed in Grapes (Ali, Pandey, Singh, \& Joshi, 2016) peach (Hazrati, Kashkooli, Habibzadeh, Tahmasebi-Sarvestani, \& Sadeghi, 2017) and sweet cherry (Serrano et al., 2017) upon Aloe vera coating. Probably, the ability of Aloe vera coating to limit moisture loss contributed to the reduced firmness of the fruit. Indeed, loss of fruit firmness or fruit softening is reported to be caused by moisture loss and pectin degradation (Mohebbi, Hasanpour, Ansarifar, \& Amiryousefi, 2014).

The pre-treatment of eggplants with citrate did not improve fruit firmness compared to the Aloe vera coated fruit. At ambient- storage temperature, differences in fruit firmness between coated and uncoated eggplant fruit was not significant, showing that low temperature storage is still relevant for decreasing firmness loss of fruit after Aloe vera coating.

\subsection{Effect of Coating on Color of Eggplant Fruit}

Lightness $\left(\mathrm{L}^{*}\right)$ values decreased gradually while red/green $\left(\mathrm{a}^{*}\right)$ and yellow/blue $\left(\mathrm{b}^{*}\right)$ values increased for all fruit during storage (Figure 3). Uncoated fruit showed a significant reduction in $\mathrm{L}^{*}$ but higher $\mathrm{a}^{*}$ and $\mathrm{b}^{*}$ values compared to the coated fruit, meaning that coating was important for retaining eggplant fruit lightness and delaying changes in color intensity during low storage temperature. Aloe vera coating is reported to cause a delay in ripening-induced color changes by slowing down fruit respiration (Chrysargyris et al., 2016). Similarly, reports showing delayed colour changes in peach (Hazrati et al., 2017) and suppression of green color loss in 'Granny Smith' apples (Ergun \& Satici, 2012) emphasize the broad application range of Aloe vera gels as a fruit coating. Considering that color is one of the most important attributes of eggplants, the ability of Aloe vera gel to delay color changes can prove very useful in preserving the quality of the fruit after harvest. 


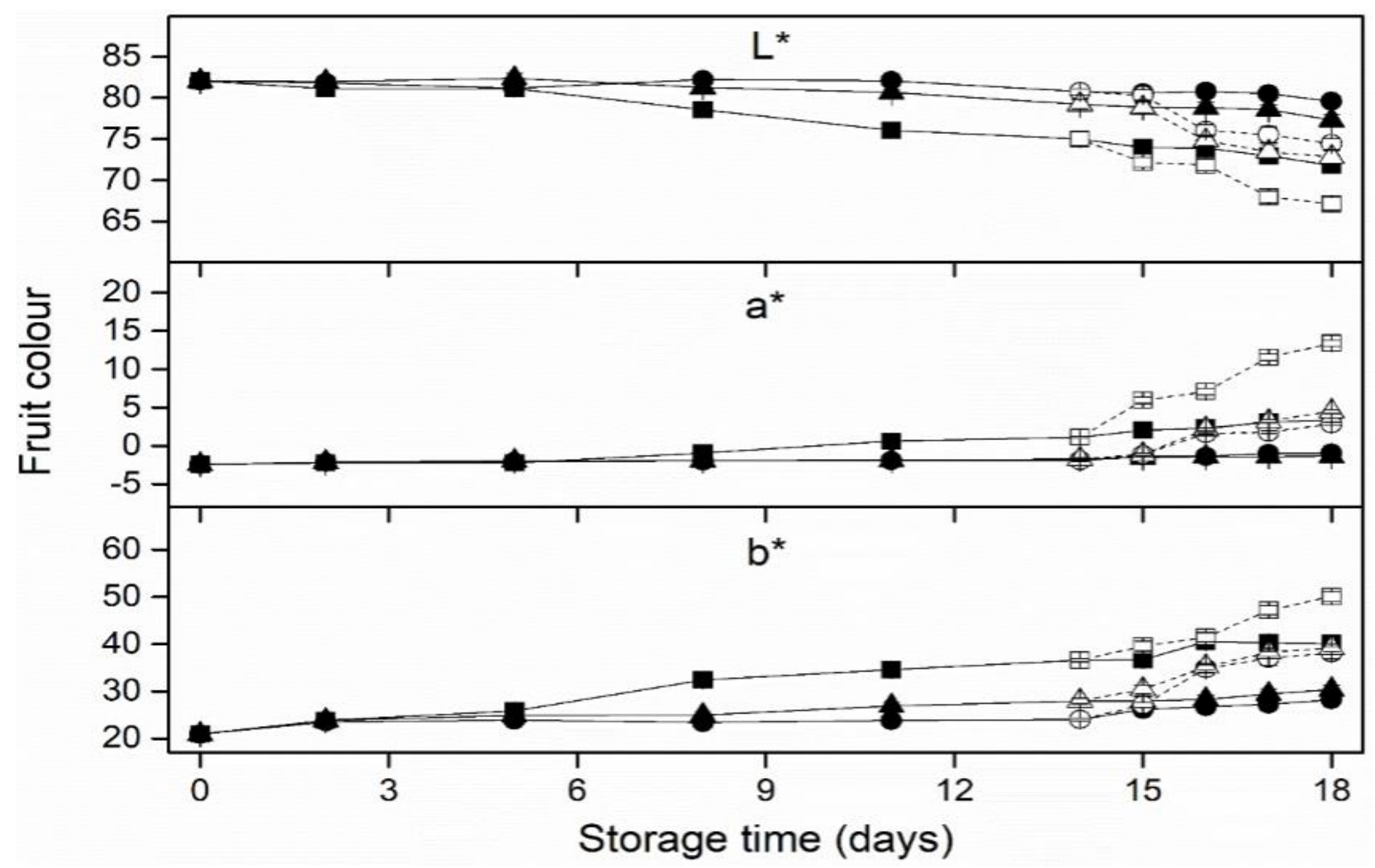

Figure-3. Color $\left(\mathrm{L}^{*} \mathrm{a}^{*} \mathrm{~b}^{*}\right)$ changes of eggplant fruit during storage at $10{ }^{\circ} \mathrm{C}$ (solid lines) [control fruit (匹); Aloe vera coated fruit $(\bullet)$; citrate pretreated Aloe vera coated fruit $(\boldsymbol{\Delta})]$ and upon transfer to room temperature (dashed lines) after 15 days [control fruit ( $\square$ ); Aloe vera coated fruit $(0)$; citrate pre-treated Aloe vera coated fruit $(\Delta)]$.

Transfer of fruit to ambient storage temperature after $14 \mathrm{~d}$ resulted in a more rapid change of color compared to those stored at low temperature. The change in color can be ascribed to increase in the metabolic rates caused by the higher storage temperature, and can contribute to fruit ripening and senescence.

\subsection{Effect of Coating on Phenolic Content, Ascorbate Levels and Antioxidant Capacity}

Phenolic, ascorbate content and antioxidant capacity of eggfruit are useful indicators of free-radical scavenging property, which have been shown to have beneficial effects on human health (Cavallo, Horino, \& McCarthy, 2016). An increasing trend in the phenolic content of eggplant fruit during storage was observed Table 1 while ascorbate levels varied relatively throughout the storage period Table 2. This observation is opposite to observed in several fruit where Aloe vera have been observed to improve the ascorbate content of coated fruit (Ali et al., 2016; Chrysargyris et al., 2016; Khatri, Panigrahi, Prajapati, \& Bariya, 2020; Rasouli, Saba, \& Ramezanian, 2019). Relatively higher ascorbate levels were observed for fruit that remained at low temperature compared to fruit transferred to room temperature. A similar decrease in ascorbate levels was observed in broccoli florets when transferred from low to room temperature storage for 24 h (Paradis et al., 1996).

Table 3 shows that the antioxidant capacity of all fruit increased during storage. Several reports showed variable effects of storage condition on antioxidant properties of fruit. Also, Dadzie et al. (2019) observed an increase in antioxidant property of eggplant fruit during cold storage, confirming reports of other studies that showed that antioxidant capacity of fruit either remain steady or increase during storage (Castricini, Coneglian, \& Deliza, 2012; Gao et al., 2015).

In this study, the application of coatings to eggplant fruit contributed to the accumulation of phenolic compounds and ascorbate, causing an increase in the antioxidant capacity of the fruit showing that the potential health benefits of the fruit can be preserved upon Aloe vera gel coating. 
Table-1. Total phenolic content of eggplant fruit coated during storage.

\begin{tabular}{|c|c|c|c|c|c|c|c|c|c|}
\hline \multirow{3}{*}{$\frac{\text { Days }}{0}$} & \multicolumn{9}{|c|}{ Total Phenolic Content (mg/kg) } \\
\hline & \multicolumn{3}{|c|}{ Control fruit } & \multicolumn{3}{|c|}{ Aloe vera coated fruit } & \multicolumn{3}{|c|}{ Citrate pre-treated Aloe vera coated fruit } \\
\hline & 220.48 & \pm & $4.24^{\mathrm{A}}$ & & - & & & - & \\
\hline 2 & 214.87 & \pm & $2.22^{\mathrm{aA}}$ & 247.88 & \pm & $0.68^{\mathrm{bA}}$ & 199.49 & \pm & $4.34^{\mathrm{aA}}$ \\
\hline 5 & 261.35 & \pm & $2.04^{\mathrm{aB}}$ & 214.23 & \pm & $2.72^{\mathrm{aA}}$ & 241.15 & \pm & $9.47^{\mathrm{aA}}$ \\
\hline 8 & 241.79 & \pm & $4.00^{\mathrm{aAB}}$ & 256.54 & \pm & $1.36^{\mathrm{aA}}$ & 207.82 & \pm & $8.72^{\mathrm{bA}}$ \\
\hline 11 & 322.88 & \pm & $6.12^{\mathrm{aB}}$ & 254.62 & \pm & $5.44^{\mathrm{bA}}$ & 261.03 & \pm & $6.55^{\mathrm{bA}}$ \\
\hline 14 & 280.58 & \pm & $11.56^{\mathrm{aB}}$ & 227.69 & \pm & $5.44^{\mathrm{aB}}$ & 274.49 & \pm & $8.72^{\mathrm{aAB}}$ \\
\hline 15 & 347.88 & \pm & $6.12^{\mathrm{aB}}$ & 323.85 & \pm & $5.44^{\mathrm{aC}}$ & 308.46 & \pm & $8.65^{\mathrm{aB}}$ \\
\hline 16 & 342.44 & \pm & $5.8 \mathrm{O}^{\mathrm{aB}}$ & 241.15 & \pm & $3.85^{\mathrm{bA}}$ & 343.08 & \pm & $10.58^{\mathrm{aB}}$ \\
\hline 17 & 308.46 & \pm & $7.49^{\mathrm{aB}}$ & 317.12 & \pm & $12.92^{\mathrm{aC}}$ & 281.06 & \pm & $8.65^{\mathrm{aB}}$ \\
\hline 18 & 357.98 & \pm & $3.71^{\mathrm{aB}}$ & 333.46 & \pm & $2.72^{\mathrm{aD}}$ & 246.92 & \pm & $7.26^{\mathrm{bA}}$ \\
\hline $15^{*}$ & 375.29 & \pm & $11.56^{\mathrm{aA}}$ & 342.12 & \pm & $3.4 \mathrm{O}^{\mathrm{aA}}$ & 308.46 & \pm & $4.08^{\mathrm{aA}}$ \\
\hline $16^{*}$ & 376.73 & \pm & $25.06^{\mathrm{aA}}$ & 439.23 & \pm & $6.93^{\mathrm{aB}}$ & 443.08 & \pm & $9.17^{\mathrm{aB}}$ \\
\hline $17 *$ & 364.71 & \pm & $18.31^{\mathrm{aA}}$ & 373.85 & \pm & $12.24^{\mathrm{aA}}$ & 401.73 & \pm & $7.48^{\mathrm{aBC}}$ \\
\hline $18^{*}$ & 365.19 & \pm & $26.33^{\mathrm{aA}}$ & 493.08 & \pm & $6.73^{\mathrm{bC}}$ & 368.08 & \pm & $8.65^{\mathrm{aC}}$ \\
\hline
\end{tabular}
case letters in a column for storage days are significantly different.

Table-2. Ascorbic acid levels of eggplant fruit during storage.

\begin{tabular}{c|c|c|c|c|c|c|c|c|c}
\hline \multirow{2}{*}{ Days } & \multicolumn{9}{|c}{ Ascorbic Acid Levels (mg/kg) } \\
\cline { 2 - 11 } & \multicolumn{3}{|c|}{ Control fruit } & \multicolumn{1}{c}{ Aloe era coated fruit } & \multicolumn{2}{c}{ Citrate pre-treated Aloe vera coated fruit } \\
\hline 0 & 248.78 & \pm & $3.58^{\mathrm{A}}$ & & - & & & - & \\
\hline 2 & 278.85 & \pm & $13.33^{\mathrm{aA}}$ & 227.39 & \pm & $4.35^{\mathrm{bA}}$ & 255.88 & \pm & \multicolumn{2}{c}{$1.67^{\mathrm{aA}}$} \\
\hline 5 & 294.90 & \pm & $4.66^{\mathrm{aAB}}$ & 268.89 & \pm & $7.52^{\mathrm{aB}}$ & 201.91 & \pm & $8.87^{\mathrm{bB}}$ \\
\hline 8 & 266.69 & \pm & $0.96^{\mathrm{aA}}$ & 256.10 & \pm & $1.95^{\mathrm{aA}}$ & 282.06 & \pm & $2.27^{\mathrm{bAC}}$ \\
\hline 11 & 277.16 & \pm & $8.12^{\mathrm{aA}}$ & 236.11 & \pm & $3.70^{\mathrm{abA}}$ & 207.45 & \pm & $5.53^{\mathrm{bB}}$ \\
\hline 14 & 239.32 & \pm & $9.56^{\mathrm{aA}}$ & 199.63 & \pm & $8.24^{\mathrm{aA}}$ & 303.29 & \pm & $7.20^{\mathrm{bBC}}$ \\
\hline 15 & 132.91 & \pm & $7.17^{\mathrm{aB}}$ & 114.66 & \pm & $4.03^{\mathrm{abB}}$ & 152.50 & \pm & $6.98 \mathrm{~b}^{\mathrm{cB}}$ \\
\hline 16 & 227.84 & \pm & $6.44^{\mathrm{aA}}$ & 148.11 & \pm & $2.63^{\mathrm{bB}}$ & 154.70 & \pm & $11.11^{\mathrm{bB}}$ \\
\hline 17 & 325.64 & \pm & $6.57^{\mathrm{aB}}$ & 213.31 & \pm & $10.03^{\mathrm{bA}}$ & 214.83 & \pm & $7.76^{\mathrm{bC}}$ \\
\hline 18 & 249.38 & \pm & $24.96^{\mathrm{aA}}$ & 288.31 & \pm & $9.32^{\mathrm{aB}}$ & 251.82 & \pm & $7.17^{\mathrm{aA}}$ \\
\hline $15^{*}$ & 90.42 & \pm & $8.12^{\mathrm{aA}}$ & 124.23 & \pm & $0.76^{\mathrm{aA}}$ & 183.24 & \pm & $15.53^{\mathrm{bA}}$ \\
\hline $17^{*}$ & 102.08 & \pm & $6.97^{\mathrm{aA}}$ & 129.19 & \pm & $2.15^{\mathrm{abA}}$ & 151.66 & \pm & $6.81^{\mathrm{bA}}$ \\
\hline $18^{*}$ & 124.46 & \pm & $6.93^{\mathrm{aA}}$ & 145.97 & \pm & $8.14^{\mathrm{aB}}$ & 141.69 & \pm & $7.27^{\mathrm{aB}}$ \\
\hline
\end{tabular}

Note: *Fruit transferred to room temperature for shelf life studies. Means not sharing the same lower-case letters in a row for coating treatment or uppercase letters in a column for storage days are significantly different.

Table-3. Total antioxidant capacity of eggplant fruit during storage.

\begin{tabular}{c|c|c|c|c|c|c|c|c|c}
\hline \multirow{2}{*}{ Days } & \multicolumn{9}{c}{ Total Antioxidant Capacity (mg/kg) } \\
\cline { 2 - 10 } & \multicolumn{3}{|c}{ Control } & \multicolumn{3}{c}{ Aloe vera coated fruit } & \multicolumn{3}{c}{ Citrate pre-treated -Aloe vera coated fru t } \\
\hline 0 & 495.41 & \pm & $3.29^{\mathrm{A}}$ & & - & & & - & \\
\hline 2 & 502.23 & \pm & $7.27^{\mathrm{aA}}$ & 502.82 & \pm & $2.56^{\mathrm{aA}}$ & 507.8 & \pm & $2.98^{\mathrm{aA}}$ \\
\hline 5 & 512.66 & \pm & $4.50^{\mathrm{aA}}$ & 508.51 & \pm & $5.09^{\mathrm{aA}}$ & 511.95 & \pm & $4.97^{\mathrm{aA}}$ \\
\hline 8 & 502.27 & \pm & $6.86^{\mathrm{aA}}$ & 508.63 & \pm & $1.78^{\mathrm{aA}}$ & 511 & \pm & $3.04^{\mathrm{aA}}$ \\
\hline 11 & 524.08 & \pm & $2.50^{\mathrm{aA}}$ & 509.62 & \pm & $1.79^{\mathrm{bA}}$ & 517.5 & \pm & $1.91^{\mathrm{aA}}$ \\
\hline 14 & 543.17 & \pm & $1.67^{\mathrm{aB}}$ & 544.03 & \pm & $2.67^{\mathrm{aB}}$ & 544.71 & \pm & $6.55^{\mathrm{aB}}$ \\
\hline 15 & 582.75 & \pm & $8.65^{\mathrm{aBC}}$ & 550.35 & \pm & $3.08^{\mathrm{bB}}$ & 568.22 & \pm & $6.88^{\mathrm{aB}}$ \\
\hline 16 & 562.26 & \pm & $5.57^{\mathrm{aBC}}$ & 575.11 & \pm & $4.91^{\mathrm{aB}}$ & 574.18 & \pm & $11.37^{\mathrm{aB}}$ \\
\hline 17 & 559.83 & \pm & $5.25^{\mathrm{aBC}}$ & 569.1 & \pm & $7.63^{\mathrm{aB}}$ & 578.65 & \pm & $3.32^{\mathrm{aB}}$ \\
\hline 18 & 578.84 & \pm & $8.13^{\mathrm{aC}}$ & 590.4 & \pm & $5.65^{\mathrm{aB}}$ & 569.34 & \pm & $1.15^{\mathrm{aB}}$ \\
\hline $15^{*}$ & 539.71 & \pm & $4.22^{\mathrm{aA}}$ & 555.11 & \pm & $5.33^{\mathrm{aA}}$ & 561.51 & \pm & $2.64^{\mathrm{aA}}$ \\
\hline $16^{*}$ & 574.24 & \pm & $1.67^{\mathrm{aB}}$ & 553.13 & \pm & $5.80^{\mathrm{aA}}$ & 578.84 & \pm & $2.90^{\mathrm{aA}}$ \\
\hline $17^{*}$ & 561.33 & \pm & $7.11^{\mathrm{aA}}$ & 573.25 & \pm & $5.80^{\mathrm{aA}}$ & 578.09 & \pm & $7.03^{\mathrm{aA}}$ \\
\hline $18^{*}$ & 592.26 & \pm & $1.84^{\mathrm{aB}}$ & 577.72 & \pm & $1.62^{\mathrm{aA}}$ & 587.78 & \pm & $3.95^{\mathrm{aA}}$ \\
\hline
\end{tabular}

Note: *Fruit transferred to room temperature for shelf life studies. Means not sharing the same lower-case letters in a row for coating treatment or upper-case letters in a column for storage days are significantly different. 


\subsection{Correlation and Association Among the Physicochemical Parameters and Coating Conditions}

Figure 4 shows a bi-plot of the first and second principal components from the PCA analysis. Separation between the control and the two coating conditions could be achieved using the first two principal components. Together these two principal components accounted for $78 \%$ of the explained variance. The bi-plot also show how the coating conditions correlated with the measure physicochemical properties. Physicochemical parameters found around a given coating condition indicate a close association with that coating condition. For example, $\mathrm{a}^{*}$ - $_{-}$and $\mathrm{b}^{*}$ values were closely associated with the control fruit, showing that fruit colour was significanlty afffcted in the control fruit. Pearson correlation analyses also revealed a strong negative correlation between weight loss and firmness, which can also be observed in the bi-plot of Figure 4.

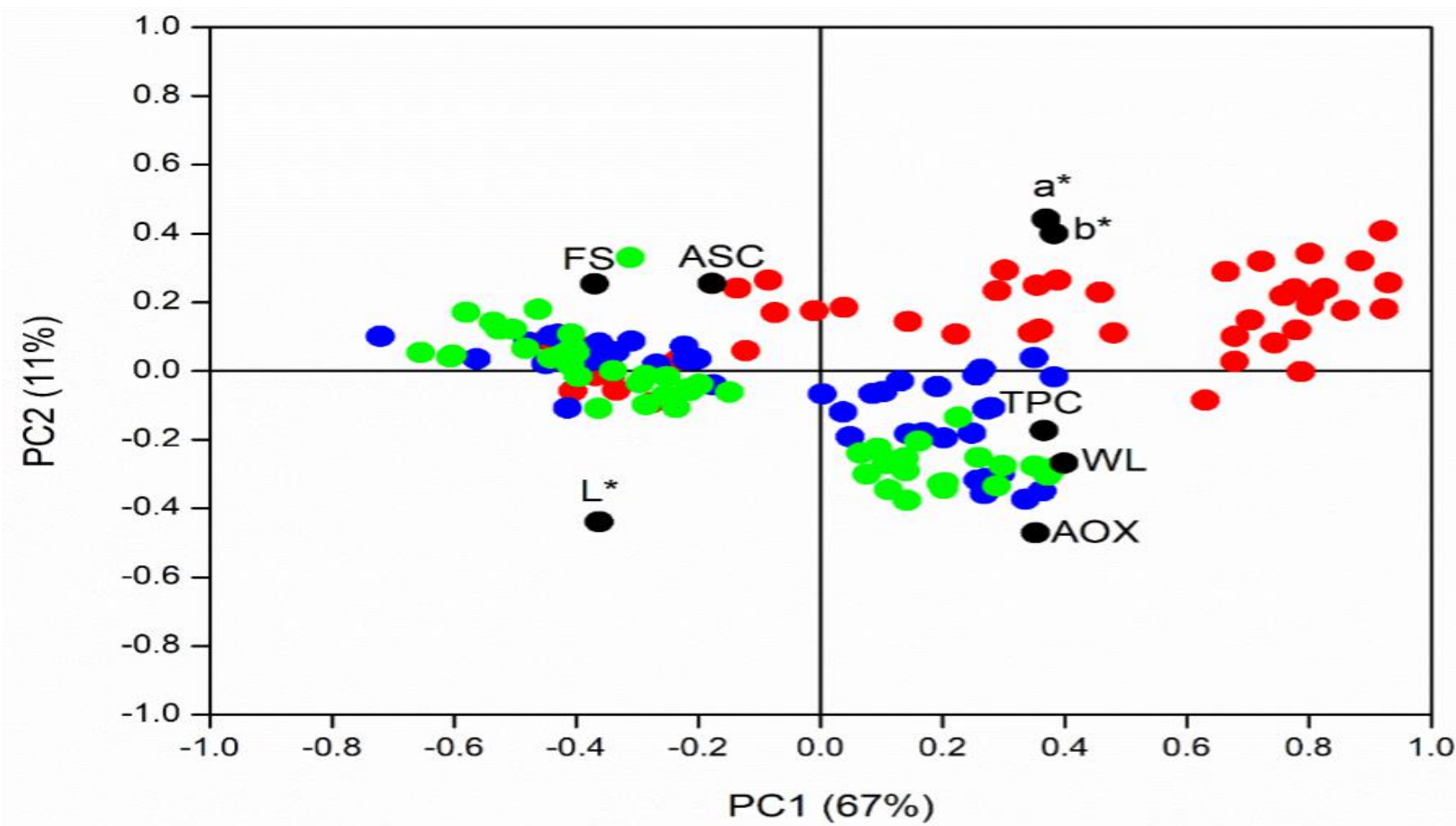

Figure-4. PCA bi-plot (PC1 is plotted against PC2) showing eggplant fruit at the different coating conditions. The samples scores (control fruitred; beeswax-coated fruit- green; citrate-treated-beeswax-coated fruit- blue) is superimposed on the loadings (AOX- total antioxidant capacity; ASC- ascorbate; FS- firmness; TPC- total phenolic content; WL- weight loss; L* value; $a^{*}$ value; $b^{*}$ value).

\section{CONCLUSIONS}

Coating of eggplant fruit with Aloe vera gel minimized weight and firmness loss, and delayed color changes during storage. Pre-treatment of fruit with citrate prior to coating did not improve the qualities of the fruit. Aloe vera gel coating helped to preserve the phenolic content, ascorbate levels and antioxidant capacity. The coating also minimized weight and firmness losses, and color changes when fruit were transferred to room temperature. This shows that Aloe vera gel coating can be applied to help maintain the quality of eggplant fruit during low temperature storage.

Funding: This study received no specific financial support.

Competing Interests: The authors declare that they have no competing interests.

Acknowledgement: All authors contributed equally to the conception and design of the study.

\section{REFERENCES}

Ali, J., Pandey, S., Singh, V., \& Joshi, P. (2016). Effect of coating of aloe vera gelon shelf life of grapes. Current Research in Nutrition and Food Science Journal, 4(1), 58-68. Available at: https://doi.org/10.12944/crnfsj.4.1.08. 
Castricini, A., Coneglian, R. C. C., \& Deliza, R. (2012). Starch edible coating of papaya: Effect on sensory characteristics. Food Science and Technology, 32(1), 84-92. Available at: https://doi.org/10.1590/s0 101-20612012005000016.

Cavallo, D. N., Horino, M., \& McCarthy, W. J. (2016). Adult intake of minimally processed fruits and vegetables: Associations with cardiometabolic disease risk factors. Journal of the Academy of Nutrition and Dietetics, 116(9), 1387-1394. Available at: https://doi.org/10.1016/j.jand.2016.03.019.

Chrysargyris, A., Nikou, A., \& Tzortzakis, N. (2016). Effectiveness of Aloe vera gel coating for maintaining tomato fruit quality. New Zealand Journal of Crop and Horticultural Science, 44(3), 203-217. Available at: https://doi.org/10.1080/01140671.2016.1181661.

Dadzie, R. G., Amoah, R. S., Ampofo-Asiama, J., Quaye, B., \& Abano, E. E. (2019). Physicochemical properties of eggplant (Solanum aethiopicum L.) fruits as affected by cassava starch coating during low temperature storage: Optimisation of coating conditions. International Journal of Postharvest Technology and Innovation, 6(4), 276-300. Available at: https://doi.org/10.1504/ijpti.2019.10028130.

Ergun, M., \& Satici, F. (2012). Use of Aloe vera as bio-preservative for 'Granny Smith' and 'red chief' apples. The Journal of Animal \& Plant Sciences, 22(2), 363-368. Available at: https://doi.org/10.31248/RJFSN2019.070.

Gao, H., Kang, L., Liu, Q., Cheng, N., Wang, B., \& Cao, W. (2015). Effect of 24 epibrassinolide treatment on the metabolism of eggplant fruits in relation to development of pulp browning under chilling stress. Journal of Food Science and Technology, 52(6), 3394 3401. Available at: https://doi.org/10.1007/s 13197-014-1402-y.

Hazrati, S., Kashkooli, A. B., Habibzadeh, F., Tahmasebi-Sarvestani, Z., \& Sadeghi, A. R. (2017). Evaluation of Aloe vera gel as an alternative edible coating for peach fruits during cold storage period. Gesunde Pflanzen, 69(3), 131-137. Available at: https://doi.org/10.1007/s10343-017-0397-5.

Khatri, D., Panigrahi, J., Prajapati, A., \& Bariya, H. (2020). Attributes of Aloe vera gel and chitosan treatments on the quality and biochemical traits of post-harvest tomatoes. Scientia Horticulturae, 259, 108837. Available at: https://doi.org/10.1016/j.scienta.2019.108837.

Kitinoja, L., \& AlHassan, H. (2012). Identification of appropriate postharvest technologies for improving market access and incomes for small horticultural farmers in Sub-Saharan Africa and South Asia. Acta Horticulturae, 934, 3 1-40. Available at: https://doi.org/10.17660/actahortic.2012.934.1.

Mohebbi, M., Hasanpour, N., Ansarifar, E., \& Amiryousefi, M. R. (2014). Physicochemical properties of bell pepper and kinetics of its color change influenced by Aloe vera and gum tragacanth coatings during storage at different temperatures. Journal of food Processing and Preservation, 38(2), 684-693. Available at: https://doi.org/10.1111/jfpp.12018.

Nicolau-Lapena, I., Colas-Meda, P., Alegre, I., Aguilo-Aguayo, I., Muranyi, P., \& Vinas, I. (2021). Aloe vera gel: An update on its use as a functional edible coating to preserve fruits and vegetables. Progress in Organic Coatings, 151, 106007. Available at: https://doi.org/10.1016/j.porgcoat.2020.106007.

Owusu-Ansah, F., Afreh-Nuamah, K., Obeng-Ofori, D., \& Ofosu-Budu, K. (2001). Managing infestation levels of major insect pests of garden eggs (Solanum integrifolium L.) with aqueous neem seed extracts. Journal of the Ghana Science Association, 3(3), 70-84. Available at: https://doi.org/10.4314/jgsa.v3i3.17769.

Paradis, C., Castaigne, F., Desrosiers, T., Fortin, J., Rodrigue, N., \& Willemot, C. (1996). Sensory, nutrient and chlorophyll changes in broccoli florets during controlled atmosphere storage. Journal of Food Quality, 19(4), 303-316. Available at: https://doi.org/10.1111/j.1745-4557.1996.tbo0425.x.

Rasouli, M., Saba, M. K., \& Ramezanian, A. (2019). Inhibitory effect of salicylic acid and Aloe vera gel edible coating on microbial load and chilling injury of orange fruit. Scientia Horticulturae, 247, 27-34. Available at: https://doi.org/10.1016/j.scienta.2018.12.004.

Serrano, M., Castillo, S., Valero, D., Valverde, J., Guille, F., \& Mart, D. (2017). Effect of Aloe vera gel treatment on bioactive compounds and antioxidant activity during storage of sweet cherry. Acta Horticulturae, 1161, 607-612. Available at: https://doi.org/10.17660/actahortic.2017.1161.97. 
Sharmin, M., Islam, M., \& Alim, M. (2015). Shelf-life enhancement of papaya with aloe vera gel coating at ambient temperature.
Journal of the Bangladesh
Agricultural
University,
$13(1)$
$131-136$.
Available
at:

https://doi.org/10.3329/jbau.v13i1.28729.

Singh, S., Khemariya, P., Rai, A., Rai, A. C., Koley, T. K., \& Singh, B. (2016). Carnauba wax-based edible coating enhances shelflife and retain quality of eggplant (Solanum melongena) fruits. $L W T, 74,420-426$. Available at: https://doi.org/10.1016/j.lwt.2016.08.004.

Views and opinions expressed in this article are the views and opinions of the author(s), Journal of Food Technology Research shall not be responsible or answerable for any loss, damage or liability etc. caused in relation to/arising out of the use of the content. 